\title{
Harvesting of common reed in the national nature park "Pyriatynskyi" (Ukraine): capacity and opportunities for nature protected area management
}

\author{
OKSANA S. ABDULOIEVA \\ ANATOLIY V. PODOBAYLO
}

\begin{abstract}
Abduloieva O.S., Podobaylo A.V. (2014). Harvesting of common reed in the national nature park "Pyriatynskyi" (Ukraine): capacity and opportunities for nature protected area management. Chornomors'k. bot. z., 10 (4): 527-539. doi:10.14255/23089628/14.104/7.
\end{abstract}

\begin{abstract}
The aim of study was to estimate resource funds of common reed and response of reed stands to harvesting in the Central Ukraine, within the national nature park "Pyriatynskyi", and uncover possibilities and consequences of regular reed harvesting for rehabilitation and sustainable management practice of floodplain in the park. By sampling three large sites of reeds differed by duration of flooding we estimated morphometric values, above-ground airdried biomass of reed and some rates of plant resource capacity. Results show that annual accumulation of reed biomass reaches low to upper medium values $\left(2-17 \mathrm{t}^{*}\right.$ ha. $\left.{ }^{-1}\right)$ known in temperate Europe. To conserve wetlands, to keep the floodplain and natural habitats in stable ecological mode the conditions of reed harvesting are recommended. Admissible rates of utilization of common reed through winter harvesting were stated. Based on indicator values obtained on sample plots an expected yield was predicted. There was confirmed no significant response of reed stands to winter harvesting in the first growing year after harvesting.
\end{abstract}

Keywords: Phragmites australis, yield, management of floodplain

АБДУЛОєВА О.С., ПоДОБАЙЛО А.В. (2014). Викошування очерету звичайного в національному природному парку «Пирятинський» (Україна): потенціал та можливості для менеджменту природоохоронної території. Чорноморськ. бот. ж., 10 (4): 527-539. doi:10.14255/2308-9628/14.104/7.

\begin{abstract}
Мета дослідження - визначити запаси очерету звичайного і реакцію очеретяних заростей на зимове викошування в одному 3 регіонів Центральної України, в національному парку «Пирятинський», а також розкрити можливості та наслідки регулярного викошування очерету в практиці відновлення та сталого управління річковою заплавою в парку. Надземна повітряно-суха біомаса очерету, морфометричні показники i деякі показники запасів його ресурсів оцінили за допомогою вибірки з трьох великих ділянок очеретяних заростей, що відрізняються тривалістю затоплення. Результати показують, що величина щорічного накопичення біомаси очерету коливається від невеликих значень до вище середніх (2-17 т/га), відомих $з$ території помірно-кліматичної Європи. Для збереження водно-болотних угідь, підтримання заплави $\mathrm{i}$ природних середовищ існування в стабільному екологічному режимі слід рекомендувати викошування очерету за певних умов. Встановлені норми допустимого використання ресурсів очерету в процесі його зимового викошування. Оцінена очікувана врожайність на підставі індикаторних значень очеретяних заростей з пробних площ. У відповідь на зимове викошування в очеретяних стеблостоях підтверджена відсутність значущої різниці в перший вегетаційний період після викошування.
\end{abstract}

Ключові слова: Phragmites australis, врожайність, управління річковою заплавою

(C) Oksana S. Abduloieva, Anatoliy V. Podobaylo

Чорноморськ. бот. ж., 10 (4): 527-539. 
АБДУЛОЕВА О.С., ПоДОБАЙЛО А.В. (2014). Выкашивание тростника обыкновенного в национальном природном парке «Пирятинский» (Украина): потенциал и возможности для менеджмента природоохранной территории. Черноморск. бот. ж., 10 (4): 527-539. doi:10.14255/2308-9628/14.104/7.

\begin{abstract}
Цель исследования - определить запасы тростника обыкновенного и реакцию тростниковых зарослей на зимнее выкашивание в одном из регионов Центральной Украины, в национальном парке «Пирятинский», а также раскрыть возможности и последствия регулярного выкашивания тростника в практике восстановления и устойчивого управления речной поймой в парке. Надземная воздушно-сухая биомасса тростника, морфометрические показатели и некоторые показатели запасов его ресурсов оценили с помощью выборки из трех больших участков тростниковых зарослей, отличающихся продолжительностью затопления. Результаты показывают, что величина ежегодного накопления биомассы тростника колеблется от небольших значений до выше средних (2-17 т/га), известных с территории умеренноклиматической Европы. Для сохранения водно-болотных угодий, поддержания поймы и естественных сред обитания в стабильном экологическом режиме следует рекомендовать выкашивание тростника при определенных условиях. Установлены нормы допустимого использования ресурсов тростника в процессе его зимнего выкашивания. Оценена ожидаемая урожайность на основании индикаторных значений тростниковых зарослей с пробных площадей. В ответ на зимнее выкашивание в тростниковых стеблестоях подтверждено отсутствие значимой разницы в первый вегетационный период после выкашивания.
\end{abstract}

Ключевые слова: Phragmites australis, урожайность, управление речной поймой

\title{
Introduction
}

In the national nature park "Pyriatynskyi" (hereinafter - the Park) there are huge areas of reeds (Phragmites australis (Cav.) Trin. ex Steud.), ones of the biggest in Central Ukraine. Rejection of rural activities such as cattle breeding, haymaking, building with natural materials has raised the problem of how to conserve environmental permanence of river wetlands in abandoned agricultural regions, especially on nature protected area.

Reed can restore its biomass every year thus largely saving wood for fuel. In vast reeds there is possible to harvest regularly up to 10-15 t of dry mass per hectare with keeping a balance of substances, in particular, rate of peat accumulation [WICHTMANN, JOOSTEN, 2007].

There are certain advantages in utilizing reed for biofuel as indicated in European references [GRANELI, 1984; WiCHTMANN et al., 2009; THEO VAN DER SLUIS et al., 2013]. Burning of reed exudes as much carbon dioxide as reed shoots are able to fix for a year so that a normal balance in atmosphere can be provided instead of 10-50 times higher emissions of carbon dioxide while burning the same amount of wood or coal. Combustion heat of reed pellets approximates to such of wood and peat. However, ash content in biofuel made of reed is higher than in wood and is $2-5 \%$ and more [KOMULAINEN et al., 2008; THEO VAN DER SLUIS et al., 2013] or even 10 times higher [WICHTMANN AND JOOSTEN, 2007]. This depends on the origin of reed and peculiarities of salt content in the environment of reeds.

Our goal was to determine biomass stocks of reeds in the Park and uncover the possibilities and consequences provided through regular harvesting of reed for conservation and rehabilitation of natural habitats. Thereby we stimulate development of regulations for sustainable management practices of riparian areas and floodplains, in particular, towards allowable limits of using natural resources within the nature protected area of the national importance in Ukraine. It will also be useful for monitoring floodplain ecosystems in the Park and relevant river ecocorridor. 


\section{Study area}

\section{Natural conditions of the region}

Margins of the Park (Poltava region, Ukraine): western point $50^{\circ} 18^{\prime} 54^{\prime \prime} \mathrm{N}$, $32^{\circ} 14^{\prime} 24^{\prime \prime} \mathrm{E}$; northern point - 50 $0^{\circ} 22^{\prime} 51^{\prime \prime} \mathrm{N}, 32^{\circ} 20^{\prime} 55^{\prime \prime} \mathrm{E}$; southern and eastern points $50^{\circ} 10^{\prime} 05^{\prime} \mathrm{N}, 32^{\circ} 37^{\prime} 47^{\prime \prime} \mathrm{E}$. Total area is above 12000 ha.

Wetlands of the Park lay along valleys of the Udai river and its branches and occupy about 7500 ha, near a half of which is covered by reeds. The Udai river floodplain belongs to the mixed forest-meadow type of landscapes, being 1000-5000 $\mathrm{m}$ in width. In spring it can be mostly flooded. In summer the flooding level largely depends on precipitation. In winter it freezes since the middle of December to the late February-Early March.

\section{Plant communities}

Reed communities represent plant association Phragmitetum communis (Gams 1927) Schmale 1939, alliance Phragmition communis Koch 1926, class of vegetation PhragmitoMagnocaricetea Klika in Klika et Novak 1941.

Two types of habitats of reeds are distinguished in the Park:

- Regularly flooded marshes of shallow waters. Water level is 5 to $50 \mathrm{~cm}$ deep in midsummer, substrate cumulates a lot of mud and litter deposits.

- Long but not regularly flooded fens; in the middle of summer water level is not deeper than $30-40 \mathrm{~cm}$ under the ground. Areas are peaty, covered by abundant tussocks and scattered willow bushes. Reeds are alternated with sedges and tall stands of Typha sp., Acorus calamus L., Glyceria maxima (C.Hartm.) Holmberg, Sparganium erectum L. and others belonging to the class Phragmito-Magnocaricetea.

Yield, vitality and portion of reed in the Park can depend on: duration and levels of flooding; frequency of herb removal; also - standing above-ground litter [GRANELI, 1989], accumulated organic litter [VAN DER PUTTEN et al., 1997], insect damage [Van der Toorn and Mook, 1982].

On plots with short-time flooding and without haymaking reeds are alternated with woodland of willows (Salix cinerea L., S.fragilis L.) and wood swamps of alder (Alnus glutinosa (L.) Gaertn.).

\section{Environment}

Soil cover consists both of mineral and organic soils on alluvial sandy clays, clays, mud and peat. At present there are widely occurred peaty soils and fen peats with saliniferous layers (Histosols Fibric and Terric) under the reeds.

In July-August 2013 water $\mathrm{pH}$ in the river was 7,65-8,54, content of dissolved oxygene in water ranged $0,29-11,0 \mathrm{ppm}$ in backwaters and 2,64-3,71 ppm in riverbed.

Climate features are typical for temperate Eastern Forest-Steppe bioclimatic zone (Fig. 1). Stable snow and ice cover appears since the middle of December. The ice cover keeps 2-2,5 months.

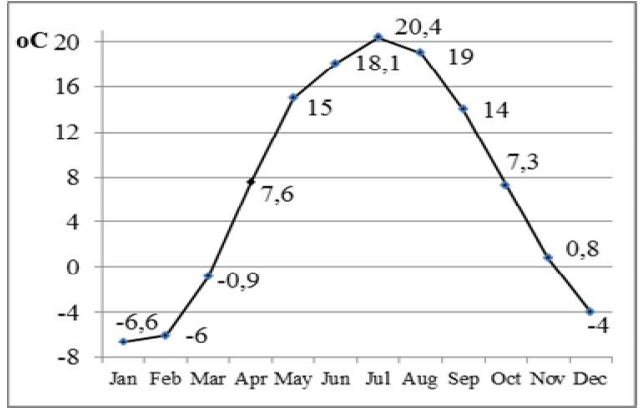

A

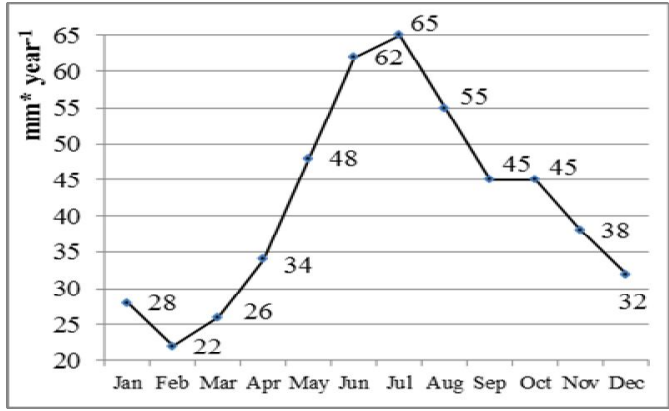

$\mathrm{B}$

Fig. 1. Average month temperatures (A) and month precipitation (B) in the region of the Park "Pyriatynskyi". Average annual precipitation amount is about $500 \mathrm{~mm}$. 


\section{Materials and methods}

Three separate tracts of reeds were selected for measurements and monitoring. Those areas are associated with floodplain of the Udai river and differ by the level and constancy of flooding. A coverage of common reed in herb stands is $90 \%$ or higher.

\section{Location of tracts and sample plots}

1 - nearby Pyriatyn town. Edge point on north-west: $50^{\circ} 13 ' 24.35^{\prime \prime N}, 32^{\circ} 32^{\prime} 47.26 " \mathrm{E}$. This tract is a part of riverbed and middle parts of floodplain. Total square is 1312,6 ha. Soil cover: fen peats solonchakous (Histosols Salic). In mid-summer groundwater is $30 \mathrm{~cm}$ under the ground surface. Floristic composition of a sample plot: Agrostis stolonifera L., Calystegia sepium (L.) R.Br., Lysimachia vulgaris L., Solanum dulcamara L., Stachys palustris L., Salix cinerea $\mathrm{L}$.

2 - nearby Kharkivtsy village. Edge point on north-east - 50 $155^{\prime} 5.87^{\prime \prime} \mathrm{N}$, $32^{\circ} 34^{\prime} 19.35 " E$. Lowland floodplain. 540 ha. Fen peaty soils saliniferous (Histosols Terric). Groundwater level is $40 \mathrm{~cm}$ under the ground surface. Floristic composition: Agrostis stolonifera, Carex acutiformis Ehrh., Butomus umbellatus L., Calystegia sepium, Carex riparia Curt., Equisetum fluviatile L., Iris pseudacorus, Lycopus europaeus L., Lysimachia vulgaris, Naumburgia thyrsiflora (L.) Reichenb, Senecio tataricus Less., Stachys palustris L., Symphytum officinale L., Caltha palustris L., Salix cinerea.

3 - nearby Keibalivka village. Edge point on north-west - 50² 18'8.28"N, $32^{\circ} 29^{\prime} 29.66 "$ "E. A riverbed and lowland floodplain. 795,3 ha. Fen peats solonchakous (Histosols Salic, or Terric). Water is always above the ground. Floristic composition: Solanum dulcamara, Stachys palustris, Calystegia sepium, Glyceria maxima, Carex riparia.

Accidental fires happen in all areas.

Mode of land using: during last 22 years it is close to complete reservation; reed has been stopped mowing, though each 2-3 years, in autumn - early spring, some part of reeds is burned off because of intentional fire-raising.

In December 2012, since a stable ice cover on the river, we recorded and mowed 5 plots, each of $100 \mathrm{~m}^{2}$ : two plots for each of the tracts No.1 and 3 and one plot in the tract No.2; in November $2013-7$ plots of $1 \mathrm{~m}^{2}$ per each $100 \mathrm{~m}^{2}$ plot. In July 2013 observations were conducted on the plots harvested in winter and on the not harvested plots close to the first ones.

No species of rare plants and animals, in particular, bird colonies, as well as rare plant communities were recorded on the plots.

\section{Quantitative measurements}

There were recorded morphometric values such as:

- Above-ground air-dried winter mass of reed.

- Stem length and diameter. Sampling size was 30 specimens in winter and 100 - in summer. Length was counted from the cutoff level (10-15 cm above ground) to the bottom of inflorescence; diameter - at the stem base near the cutoff.

- Density of reed stems - number of stems cut on the $1 \mathrm{~m}^{2}$ plot.

Reed in the Park is considered a natural resource of national importance. Reed resources are expressed through the next values:

- Expected yield is an outcome of the above-ground wet winter mass per square unit.

- Biological stocks, or resource fund of a separate tract:

$$
\mathrm{BS}_{\mathrm{i}}=\mathrm{S}_{\mathrm{i}} \times\left(\overline{\mathrm{Y}}_{\mathrm{i}}-\overline{\mathrm{m}}_{\mathrm{i}}\right)
$$

where $S_{i}$ - square of a reed tract, ha, $\bar{Y}_{i}$ - the expected yield of a sample plot, $\bar{m}_{i}-$ error of mean of the expected yield. "The yield minus error of mean" indicates a minimum yield appropriate for evaluation of $\mathrm{BS}_{\mathrm{i}}$ to avoid an over-consumption of the resource [Mynarchenko, Sereda, 2004]. 
- Operating stocks (OS) are a portion of biological stocks to be removed with keeping a minimum ability of the reeds to restore and reproduce [MYNARCHENKO, SEREDA, 2004].

An experience of Danube biosphere reserve shows that it is necessary to remove most part of winter reed and remain no less than $25 \%$ in order to keep a river floodplain in good condition. Ukrainian legal act "Instruction on the procedure for setting standards of a special using of natural plant resources" [ORDER OF THE MINISTRY OF ECOLOGY AND NATURAL RESOURCES OF UKRAINE, 12.02.2002, number 61] defines a rate of operating stocks for shoots of perennial herbal plants at 20-30\%. But as winter reed stems are dry and have already fulfilled all vegetative and reproductive functions we can recommend to define OS for winter reed stems at $50-60 \%$ of biological stocks.

$$
\mathrm{OS}_{\mathrm{i}}=\frac{\mathrm{BS}_{\mathrm{i}} \times 60 \%}{\alpha \times 100 \%}
$$

where $\mathrm{BS}_{\mathrm{i}}$ is a lower threshold of biological stocks, $60 \%$ is a recommended portion of reed resources for removal in the Park, $\alpha$ is a period of resource restoration (one year for reed which restores each year).

The proportion recommended for harvesting is 3:2, that means three parts of an area to be removed, the rest two parts should remain.

- Allowable annual harvesting capacity is such a quantity of the resource to be removed that keeps a maximum ability of reeds to restore annually.

$$
\mathrm{AAHC}_{\mathrm{i}}=\frac{\mathrm{OS}_{\mathrm{i}}}{\alpha}, \mathrm{t}^{*} \mathrm{year}^{-1} \text {. }
$$

Statistical treatment was conducted using Statistica 6. In order to estimate possible correlations between morphometric values of reed stands we used Product-moment correlation; in cases of small samplings and non-normal distribution - Spearman rank from nonparametric statistics.

\section{Winter harvesting}

\section{Results and discussion}

The expected yield of reeds in the Park ranges between low and medium values, below $5 \mathrm{t}^{*} \mathrm{ha}^{-1}$ and below $17 \mathrm{t}^{*} \mathrm{ha}^{-1}$, appropriately (tab. 1). The upper values belong to the maximum reported from the Forest-Steppe Ukraine [VAN DER SLUIS et al., 2013].

Density of the studied reeds varied in wide ranges: sometimes sparse stands occurred (up to 100 stems per $1 \mathrm{~m}^{2}$ ), sometimes - of medium (100-150 stems per $1 \mathrm{~m}^{2}$ ) or high density $(150-250)$.

In the $1^{\text {st }}$ tract reeds are characterized by low and medium density of stem stands with the average height about $2 \mathrm{~m}$. In sparse stands there are up to 100 stems per $1 \mathrm{~m}^{2}$ and in medium-dense ones - about 150 stems per $1 \mathrm{~m}^{2}$. The expected yield was $3-5 \mathrm{t}^{*} \mathrm{ha}^{-1}$.

In the $2^{\text {nd }}$ tract reed stands were sparse to medium-dense. Due to higher stem stands the expected yield increased up to 5-7 $\mathrm{t}^{*} \mathrm{ha}^{-1}$.

The $3^{\text {rd }}$ tract appeared the most productive one. This fact can be associated with regular flooded environment. Stem stands are mostly dense -200 and more stems per $1 \mathrm{~m}^{2}$. Reed stands were difficult to pass through, because of large amount of dead stems. The expected yield was about $15 \mathrm{t}^{*} \mathrm{ha}^{-1}$.

Values of common reed yield in other regions of Ukraine vary 2-23 $\mathrm{t}^{*} \mathrm{ha}^{-1}$ [DUBYNA, STUPAK, NEBESNYI, 1990], while on adjacent territories in Europe - 1,5-16 $\mathrm{t}^{*} \mathrm{ha}^{-1}$ (tab. 2).

So annual reed productivity in the given region is sufficient for introduction of reed harvesting. Under the regulations of frequency and terms, the harvesting of reed should be treated as an action to keep wetlands and other parts of river floodplains in good condition both for nature diversity and human needs in the region. 
Resource funds of common reed as a natural plant resource in the national nature park "Pyriatynskyi" based on evaluation in winter 2013

\begin{tabular}{|c|c|c|c|c|c|}
\hline $\begin{array}{c}\text { Tract and } \\
\text { plots within it }\end{array}$ & $\begin{array}{c}\text { Wet mass of winter } \\
\text { stems, } \overline{\mathrm{M}} \pm \overline{\mathrm{m}}, \\
\mathbf{k g} \text { per } \mathbf{1 0 0} \mathbf{~ m}^{\mathbf{2}}\end{array}$ & $\begin{array}{c}\text { Expected yield, } \\
\overline{\mathrm{M}} \pm \overline{\mathrm{m}}, \mathbf{t}^{* *} \mathbf{h a} \mathbf{-}^{-\mathbf{1}}\end{array}$ & Square, ha. & $\begin{array}{c}\text { Biological } \\
\text { stocks }^{\mathbf{a}}, \mathbf{t}\end{array}$ & $\begin{array}{c}\text { Allowable annual } \\
\text { harvesting capacity } \\
\mathbf{b}\end{array}$ \\
\hline $\mathbf{1}$ & $39,0 \pm 10,4$ & $3,9 \pm 1,0$ & 1312,6 & 3806,5 & 2283,9 \\
\hline $\mathbf{1 . 1}$ & $45,9 \pm 9,6$ & $4,6 \pm 1,0$ & - & - & - \\
\hline $\mathbf{1 . 2}$ & $32 \pm 11,4$ & $3,2 \pm 1,1$ & - & - & - \\
\hline $\mathbf{2}$ & $58,2 \pm 12,4$ & $5,8 \pm 1,2$ & 540 & 2862 & 1717,2 \\
\hline $\mathbf{3}$ & $153,1 \pm 11,3$ & $15,3 \pm 1,1$ & 795,3 & 11293,3 & 6775,9 \\
\hline $\mathbf{3 . 1}$ & $161 \pm 11,4$ & $16,1 \pm 1,1$ & - & - & - \\
\hline $\mathbf{3 . 2}$ & $145,1 \pm 13,0$ & $14,5 \pm 1,3$ & - & - & - \\
\hline TOTAL & - & - & - & 17961,8 & 10777,1 \\
\hline
\end{tabular}

Footnotes: "and ${ }^{\text {b }}$ - for definitions of "biological stocks" and "allowable annual harvesting capacity" see "Materials and methods".

Table 2

Range of reed biomass production according to some references

\begin{tabular}{|c|c|c|}
\hline Area, habitats & Values of yield & References \\
\hline $\begin{array}{c}\text { Ukraine, Poltava region, along the } \\
\text { Vorskla river and Uday river outside } \\
\text { the Park: } \\
\text { not flooded reeds } \\
\text { moderately and regularly flooded } \\
\text { reed wetlands }\end{array}$ & $\begin{array}{l}4,02-9,15 \mathrm{t}^{*} \mathrm{ha}^{-1} \text { of dry mass } \\
6,11-16,71 \mathrm{t}^{*} \mathrm{ha}^{-1} \text { of dry mass }\end{array}$ & [Theo van der Sluis et al., 2013] \\
\hline $\begin{array}{l}\text { Ukraine, Dnieper river delta along the } \\
\text { Black Sea coast, freshwater and } \\
\text { brackish wetlands: } \\
\text { continuously flooded plots with mud } \\
\text { soils } \\
\text { open-water plots }\end{array}$ & $\begin{array}{c}\text { In general } 2-23 \mathrm{t}^{*} \mathrm{ha}^{-1} \text { of air- } \\
\text { dried biomass } \\
\text { On the average } \\
4,95 \pm 0,4 \mathrm{~kg}^{*} \mathrm{~m}^{-2} \text { of wet mass } \\
\text { On the average } 4,8 \pm 0,82 \\
\mathrm{~kg}^{*} \mathrm{~m}^{-2} \text { of wet mass }\end{array}$ & $\begin{array}{c}\text { [Dubyna, Stupak, Nebesnyi, } \\
\text { 1990]; [Dubyna, Shelyag- } \\
\text { Sosonko, 1989] }\end{array}$ \\
\hline Ukraine, Danube biosphere reserve & $7-23 \mathrm{t}^{*} \mathrm{ha}^{-1}$ & $\begin{array}{c}\text { [Zhmud, 2006] - Report on } \\
\text { Wetland Vegetation of the } \\
\text { Danube Delta (in Ukrainian) } \\
\text { posted on } \\
\text { http://awsassets.panda.org/downlo } \\
\text { ads/zhmud_elena.pdf } \\
\end{array}$ \\
\hline Romania, Danube delta, fresh water & $9,8-16,3 \mathrm{t}^{*} \mathrm{ha}^{-1}$ & [Hanganu, Mihail, Coops, 1999] \\
\hline Germany, Seddinsee (near Berlin) & $1,520-4,200 \mathrm{t}^{*} \mathrm{ha}^{-1}$ & [Rolletschek et al., 1999] \\
\hline Southern Sweden, in August & $1000 \mathrm{~g}^{*} \mathrm{~m}^{-2}$ of dry mass & [Graneli, 1990] \\
\hline $\begin{array}{c}\text { Continental-arid North-Western } \\
\text { China, without grazing and with low } \\
\text { grazing }\end{array}$ & $4,7-6,0 \mathrm{t}^{*} \mathrm{ha}^{-1}$ & [Thevs et al., 2007] \\
\hline
\end{tabular}

Average height of reed stems in the Park is within 190-270 cm, sometimes reaches 300-360 cm (tab. 3), while in the most favorable habitats for common reed like marshes near the Black Sea coast the prevailing height range is $200-300 \mathrm{~cm}$, sometimes up to $300-400 \mathrm{~cm}$ [Dubyna, Shelyag-Sosonko, 1989]. Thus, the floodplain in the Park represents enough productive environment for growth of reed.

Each of three reed tracts being not similar in the level and frequency of flooding significantly differ from each other in stem height as well.

An average diameter of winter reed stems was $6,3-9,0 \mathrm{~mm}$; confidence interval under the current conditions of management $-6,9-7,9 \mathrm{~mm}(\mathrm{p}<0,01)$. Tract No.3 was characterized by regular flooding and significantly thicker stems that can reach 10-16 $\mathrm{mm}$ by diameter. In 
tracts without regular flooding a significant difference in stem diameter was not found $(\mathrm{p}=0,28)$.

Table 3

Morphometric data of winter reed stands in the Park

\begin{tabular}{|c|c|c|c|c|c|c|}
\hline \multirow{2}{*}{$\begin{array}{c}\text { Tract and } \\
\text { plots within } \\
\text { it }\end{array}$} & \multicolumn{2}{|c|}{ Stem height } & \multicolumn{2}{c|}{ Stem diameter } & \multicolumn{2}{c|}{ Stem density } \\
\cline { 2 - 7 } & $\begin{array}{c}\overline{\mathrm{M}} \pm \mathrm{SD}^{\mathrm{a}}, \\
\mathbf{c m}\end{array}$ & Min-max & $\begin{array}{c}\overline{\mathrm{M}} \pm \mathrm{SD}, \\
\mathbf{m m}\end{array}$ & Min-max & $\begin{array}{c}\overline{\mathrm{M}} \pm \mathrm{SD} \text {, stems per } \\
\text { running meter }\end{array}$ & $\begin{array}{c}\text { Stems } \\
\text { per } \mathbf{1} \mathbf{~ m}^{\mathbf{2}}\end{array}$ \\
\hline $\mathbf{1}$ & $200 \pm 21^{*}$ & $150-245$ & $6,5 \pm 1,2$ & $3,0-9,0$ & $9 \pm 3$ & $70-140$ \\
\hline $\mathbf{1 . 1}$ & $202 \pm 24$ & $150-245$ & $6,2 \pm 1,2$ & $3,0-9,0$ & $8 \pm 2$ & $70-110$ \\
\hline $\mathbf{1 . 2}$ & $199 \pm 18$ & $180-240$ & $7,0 \pm 1,1$ & $4,8-9,0$ & $10 \pm 4$ & $80-180$ \\
\hline $\mathbf{2}$ & $226 \pm 10^{*}$ & $210-237$ & $6,3 \pm 0,9$ & $4,5-7,8$ & $9 \pm 2$ & $85-180$ \\
\hline $\mathbf{3}$ & $271 \pm 41^{*}$ & $190-363$ & $9,0 \pm 2,0^{*}$ & $4,8-16,0$ & $11 \pm 3$ & $90-250$ \\
\hline $\mathbf{3 . 1}$ & $222 \pm 16$ & $200-245$ & $8,1 \pm 1,4$ & $5,3-12,2$ & $10 \pm 4$ & $90-250$ \\
\hline $\mathbf{3 . 2}$ & $289 \pm 35$ & $245-363$ & $9,9 \pm 2,3$ & $4,8-16,0$ & $11 \pm 3$ & $100-250$ \\
\hline TOTAL & $232 \pm 42$ & $150-363$ & $7,4 \pm 2,0$ & $3,0-16,0$ & - & - \\
\hline
\end{tabular}

Footnotes: ${ }^{\text {a }} \overline{\mathrm{M}} \pm \mathrm{SD}$ - mean and standard deviation; * - significant difference between the given tract and the rest, following t-test for independent samples, if $\mathbf{p}<0,01$.

Simple correlation between height and diameter of winter stems on the plots appeared strong $(\mathrm{r}=0,9, \mathrm{p}=0,006)$.

The sampling of stem data set shows the distribution approximating to Gaussian one, both in height and diameter (fig.2).

Gaussian distribution in a sampling occurs in locations of irregular flooding and with shallow groundwater level in summer while high and stable flooding causes skewness of sampling distribution by means of an increase in stem sizes.

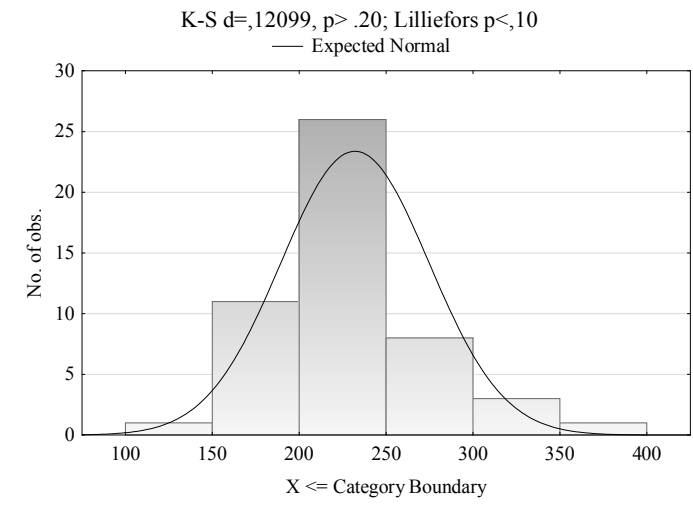

$\mathrm{H}$

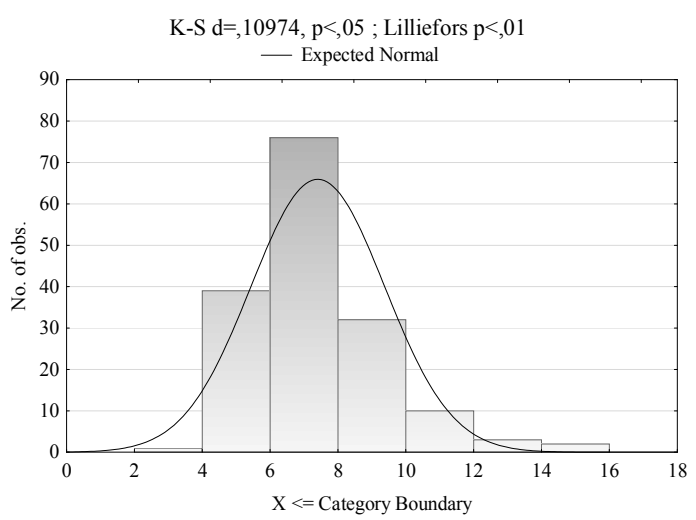

$\mathrm{D}$

Fig. 2. Examination of a sampling of reed stems in winter for Gaussian distribution: $\mathbf{H}$ - height (cm), D diameter $(\mathbf{m m})$.

Sizes of stems inside huge reed areas are values of low and medium variation: coefficient of variation varies $8-23 \%$ in stem diameter and $9-19 \%$ in stem height. Therefore, in most cases it is sufficient to record sampling of 15-20 stems per each square meter for keeping percentage error of mean under $5 \%$.

As an important result of observations in reeds there can be regarded finding correlation between morphometric data set on a plot and the expected yield. Biomass of a plot is a function of height, diameter and stem density of reed, therefore these values should be related in the linear regression equation. 


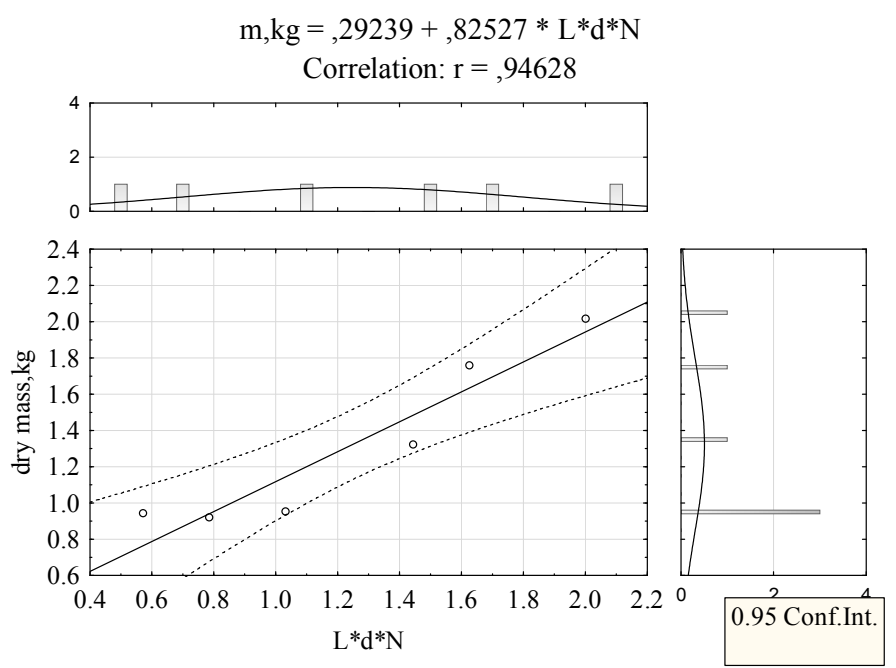

Fig. 3. Pearson correlation: $\mathrm{m}, \mathrm{kg}$ - harvested air-dried above-ground mass of reed, $\mathrm{kg}$ per $1 \mathrm{~m}^{2}, \mathrm{~L}-\mathrm{stem}$ height, $\mathrm{m}$; d-stem diameter, $\mathrm{m} ; \mathrm{N}$ - stem density per $1 \mathbf{m}^{2}$.

Through recording data set on a few plots of $1 \mathrm{~m}^{2}$ at the end of growing season, we obtained a significant strong correlation between wet mass and product of height, diameter and stem density $\left(\mathrm{L}^{*} \mathrm{~d}^{*} \mathrm{~N}\right)$ per square unit was confirmed: $\mathrm{r}=0,95, \mathrm{p}<0,01$ (fig. 3 ). Interpolation of the obtained data was useful for predicting the expected yield range as shown in Table 4.

Table 4 Interpolation of the expected yield of reed stands following morphometric data set recorded on sampling plots in the Park

\begin{tabular}{|c|c|c|c|}
\hline $\begin{array}{c}\text { Height of cut stems, } \\
\overline{\mathbf{M}}^{\mathbf{a}} \mathbf{, ~ c m}\end{array}$ & $\begin{array}{c}\text { Diameter of cut stems, } \\
\text { limits of } \overline{\mathbf{M}}^{\mathbf{a}} \mathbf{, ~ m m}\end{array}$ & $\begin{array}{c}\text { Density of winter stems } \\
\text { per } \mathbf{1} \mathbf{~ m}^{\mathbf{2}}\end{array}$ & $\begin{array}{c}\text { Expected yield, } \\
\mathbf{t}^{*} \mathbf{h a}^{\mathbf{- 1}}\end{array}$ \\
\hline $181-236$ & $5,0-8,1$ & $\begin{array}{c}70-90 \text { (sparse) } \\
90-150 \text { (medium-dense) }\end{array}$ & $2-5(7)$ \\
\hline $208-324$ & $9,5-12,2$ & $\begin{array}{c}150-250 \\
\text { (medium-dense and dense } \\
\text { stands) }\end{array}$ & $13,5-16$ \\
\hline
\end{tabular}

Footnotes: $\overline{\mathrm{M}}^{\text {a }}$ - range of means (if $\overline{\mathrm{M}} \pm \mathrm{SD}$ ).

Taking into account the received values there should be concluded that regular flooding promotes growth of reed in observed cases that means higher values of stem sizes, biomass and stem density per plot (tab. 1, 3). In other geographical and environmental conditions we can find facts confirming that denser stem stands are associated with shallower water, though intermediate depths have experienced the greatest decline [BODENSTEINER, GABRIEL, 2003].

Table 5

Average above-ground mass per $1 \mathrm{~m}^{2}$ plot of reed stands at the end of growing season in the Park

\begin{tabular}{|c|c|c|}
\hline Plant mass fractions on a plot & Wet $\mathbf{~ m a s s , ~} \mathbf{~ k}^{*} \mathbf{m}^{\mathbf{- 2}}$ & $\begin{array}{c}\text { Air-dried mass, } \\
\mathbf{~ k g *} \mathbf{~ m}^{\mathbf{2}}\end{array}$ \\
\hline Mass of harvested stems & $1,64 \pm 0,59$ & $1,31 \pm 0,47$ \\
\hline Mass of stem base remains & $0,10 \pm 0,05$ & $0,08 \pm 0,04$ \\
\hline $\begin{array}{c}\text { Mass of plant litter on the } \\
\text { ground }\end{array}$ & $0,51 \pm 0,17$ & $0,36 \pm 0,12$ \\
\hline Total above-ground plant mass & $2,27 \pm 0,70$ & $1,77 \pm 0,55$ \\
\hline
\end{tabular}

Records of stem remains and litter gave us estimating total above-ground plant mass per square unit in reeds (tab. 5). 


\section{Summer observations after winter harvesting}

In the first year after winter harvesting, in the middle of growing season (July 2013) morphometric observations were repeated within two reed areas differing in flooding stability. Reed stands formed in summer on harvested and nearby non-harvested plots differed with statistical significance (tab. 6, fig. 4). It can mean a slight decrease in the growth rate during the first half of growing season on the harvested plots. Reed stems were thinner, sometimes lower compared with the not harvested plots.

Table 6

A difference in sizes of reed stems observed next summer between the harvested in winter and nearby not harvested plots

\begin{tabular}{|c|c|c|c|c|c|c|c|c|}
\hline \multirow{2}{*}{ Values } & \multicolumn{4}{|c|}{ Tract 3, regularly flooded } & \multicolumn{3}{c|}{ Tract 2, not regularly flooded } \\
\cline { 2 - 9 } & \multicolumn{2}{|c|}{ Diameter, mm } & \multicolumn{2}{c|}{ Height, cm } & \multicolumn{2}{c|}{ Diameter, mm } & \multicolumn{2}{c|}{ Height, cm } \\
\cline { 2 - 9 } & $\mathrm{N}^{*}$ & $\mathrm{WH}^{*}$ & $\mathrm{~N}$ & $\mathrm{WH}$ & $\mathrm{N}$ & $\mathrm{WH}$ & $\mathrm{N}$ & $\mathrm{WH}$ \\
\hline$\overline{\mathrm{M}} \pm \mathrm{SD}$ & $10,6 \pm 2,6^{* *}$ & $9,3 \pm 2,4^{* *}$ & $217 \pm 59^{* *}$ & $175 \pm 51^{* *}$ & $5,1 \pm 1,4^{* *}$ & $4,4 \pm 1,2^{* *}$ & $110 \pm 26$ & $108 \pm 40$ \\
\hline mediane & 10,0 & 9,0 & 219 & 174 & 5,0 & 4,0 & 115 & 105 \\
\hline $\begin{array}{c}\mathbf{9 5 \%} \text { confidence } \\
\text { interval } \overline{\mathrm{M}} \pm \mathrm{t} * \mathrm{~m}\end{array}$ & $10,1-11,1$ & $8,8-9,7$ & $206-228$ & $166-185$ & $4,8-5,4$ & $4,2-4,6$ & $105-115$ & $100-115$ \\
\hline Min-max & $4,5-18,0$ & $4,0-15,0$ & $77-376$ & $53-308$ & $2,0-15,0$ & $2,0-8,0$ & $40-177$ & $37-205$ \\
\hline
\end{tabular}

Footnotes: * - N - a plot not harvested in winter, WH - a plot harvested last winter.

** - statistically significant difference between plots by the t-test at $\mathbf{p}<0,01$.

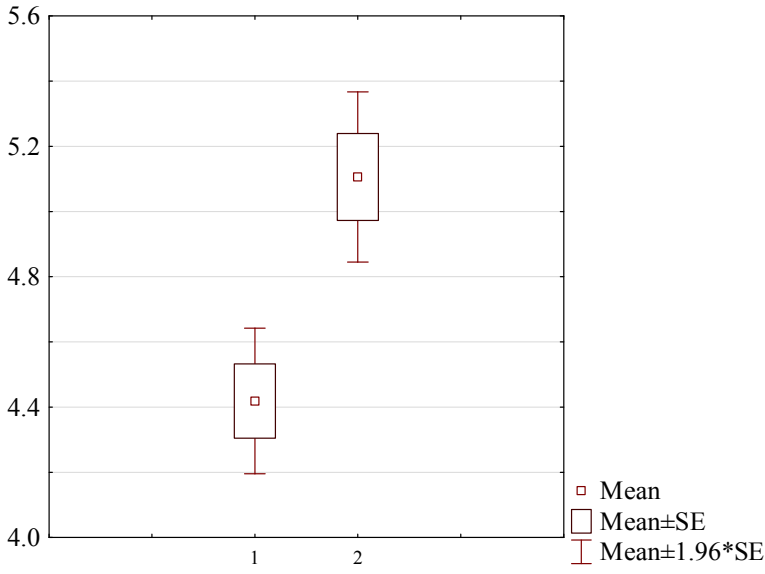

$\mathrm{D}$

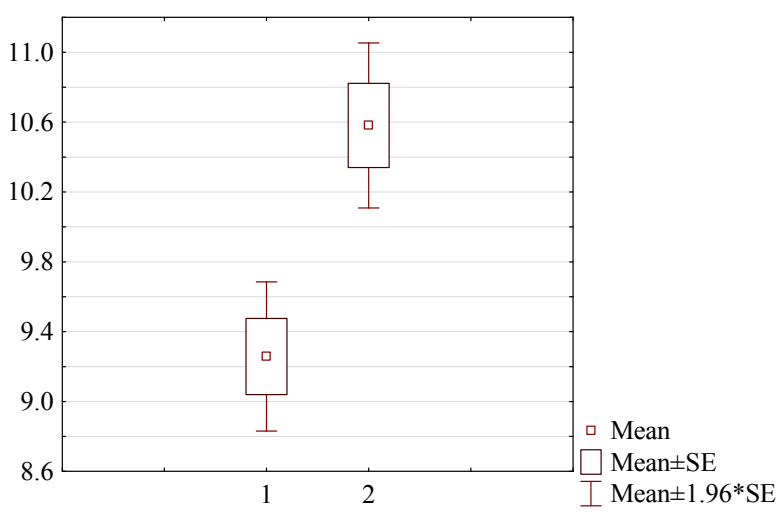

$\mathrm{D}$

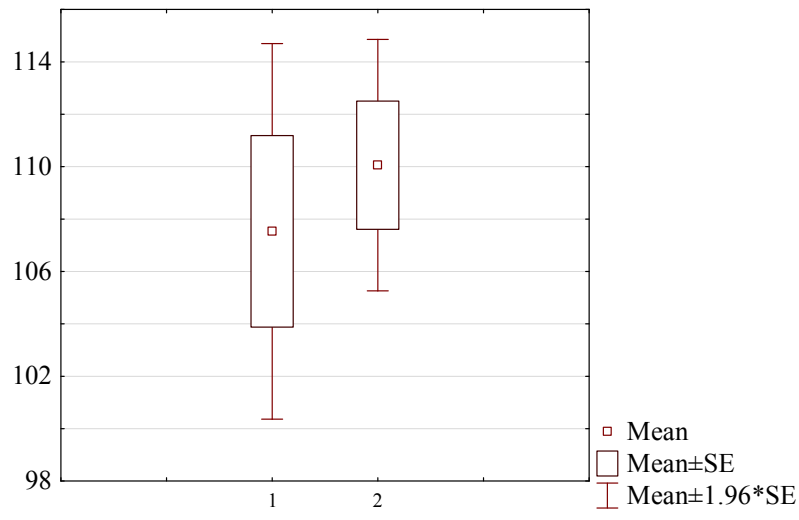

$\mathrm{H}$

TRACT 2

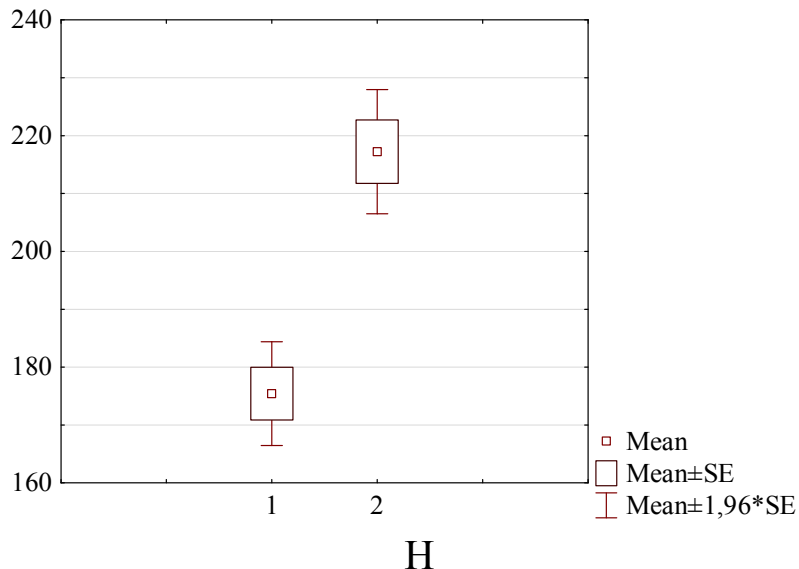

TRACT 3

Fig. 4. A difference in sizes of reed stems in the first growing season after winter harvesting. Tract 2 - not regularly flooded, tract 3 - regularly flooded. D - stem diameter, mm, H - stem height, cm. 1 - a plot of winter harvesting, 2 - a plot not harvested in winter. 
In particular, in July within the regularly flooded tract 3 a stem height was significantly lower by $19 \%$ on average on the harvested plot versus the not harvested one, stem diameter - smaller by $12 \%$ on average. Similarly, within the long-flooded tract 2 stem diameter grew more slowly by $14 \%$ on average, but there was found out no significant difference in height growth.

Nevertheless, at the end of growing season 2013 dry reed stands appeared to be of the same size and stem density per square meter as last winter 2012. Thus, a lag of the growth observed in early growing season after the first winter harvesting was overcome later.

Just as winter measurements, summer observations confirmed a significant positive but not strong correlation between height and diameter data of reed stems: for sampling of the tract 3 a Pearson correlation coefficient was 0,57 for the harvested and 0,48 for the not harvested plots, $\mathrm{p}<0,01$; on the tract $2-0,69$ and 0,28 , appropriately, $\mathrm{p}<0,01$ (fig. 5).

Thus, it should be admitted that the first winter harvesting probably does not affect the morphometric data and plant mass of reed stands next growing season after harvesting in the case of reeds not having been utilized many years before. The recorded decrease of the average diameter was $13 \%$, with statistical significance, of stem height - even less and with statistical significance not in all cases, and by the end of the year the indicated differences disappeared.

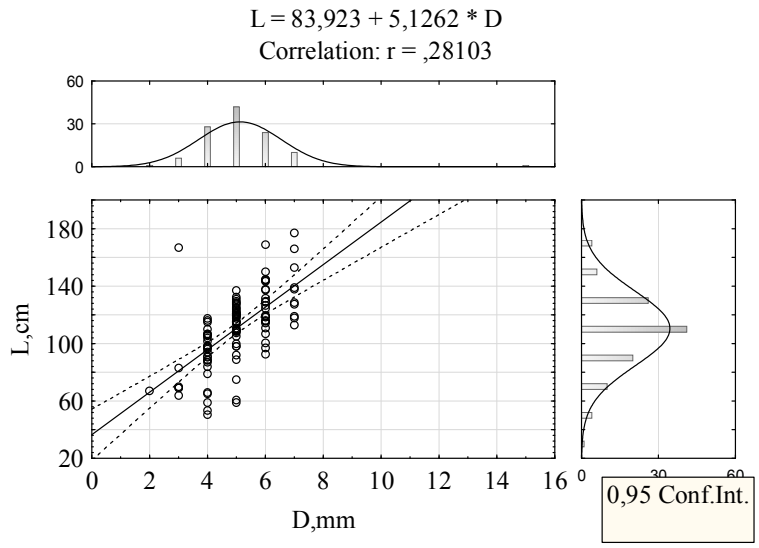

$\mathrm{Nh}_{2}$

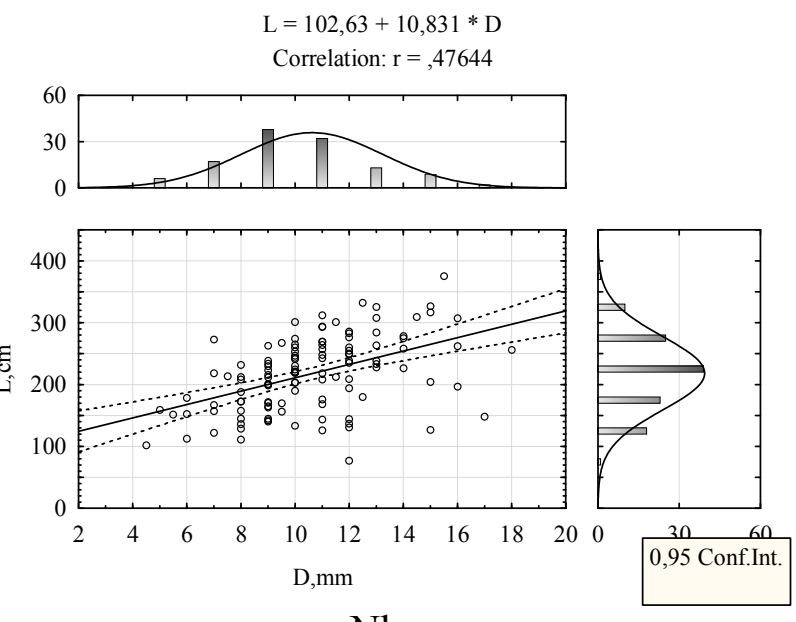

$\mathrm{Nh}_{3}$

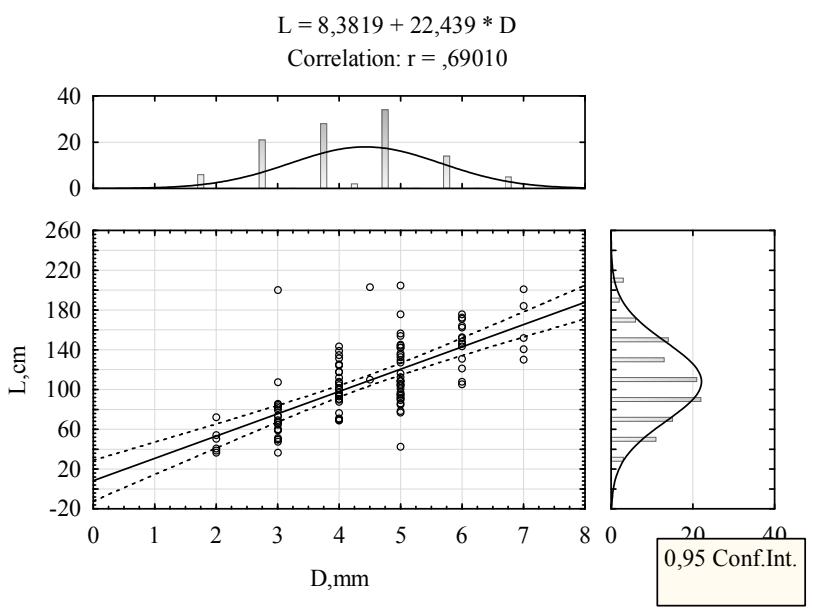

$\mathrm{H}_{2}$

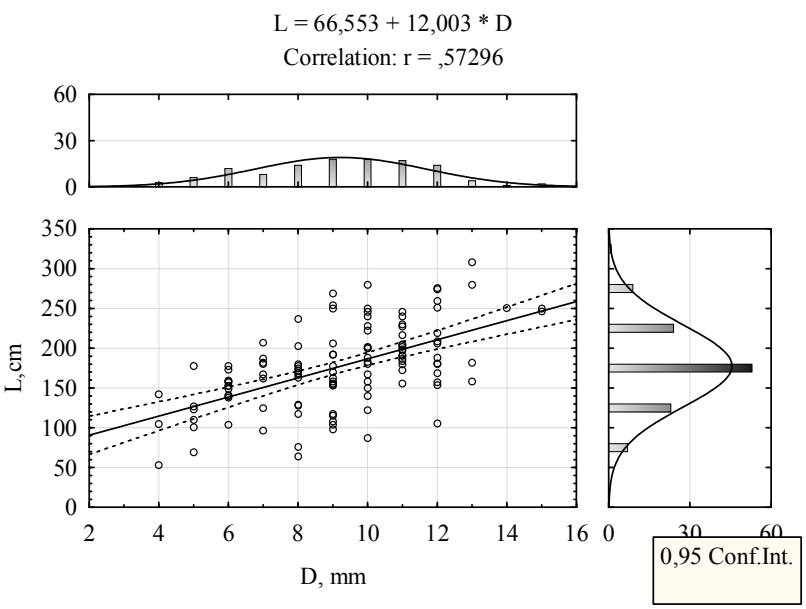

$\mathrm{H}_{3}$

Fig. 5. Regression line by size values of summer reed stems (July 2013). Tract 2 , not regularly flooded: $\mathrm{Nh}_{2}$ - a plot not harvested in winter; $\mathrm{H}_{2}$ - a plot of winter harvesting. Tract 3, regularly flooded: $\mathrm{Nh}_{3}-\mathrm{a}$ plot not harvested in winter; $\mathbf{H}_{3}$ - a plot of winter harvesting. 
In the first year of observations after harvesting a damage of reed stems by invertebrate pests varied from 40 to $56 \%$ of stems both per harvested and nearby not harvested plots.

\section{Advantages of removal of reed biomass for wetlands environment}

During Soviet Union period (since 50s till 1993-1994) reed areas along the Udai river were not large. The interested floodplain area was managed by seven community councils six of villages and one of a town. Maximum harvesting area was 5 to 30 (40) ha per village or town council. Most of floodplain was occupied by highly productive flooded meadows used for grazing or haymaking, not by reeds. It means that under intensive land use including crops, grazing of large livestock, haymaking, reeds were significantly fewer distributed. Reed was also used for producing the mats for feeding of worms of silk moth and for making roofs.

Thus, in times of traditional rural land use practices a river floodplain could incorporate higher habitat diversity. During last 20 years reeds have occupied most area of river floodplain and habitats. Nowadays every 2-3 years fires can burn down the third part of reeds.

Harvesting of some reed versus complete reservation of wetlands will save the studied floodplain and help in solving conservation and recreation objectives in the Park in such ways:

- It can hold back an increase of peat layer [WICHTMANN et al., 2009] and transforming river ecosystems towards fens. Winter mowing can keep stability of vegetation of marshes in cases when mid-summer lowering of water table happens [GRYSEELS, 1989].

- Some amount of biogenic elements is eliminated by mowing and thereby a cycle of substances is stimulated in water.

Mowing in winter does not negatively affect reed stands [GRANELI, 1990; BUTTLER, 1992; GÜSEWEL et al., 2000]. Under conditions of long flooding or shallow waters common reed is a plant of high competitiveness and vitality versus other marsh plants which seedlings are less tolerant to long flooding [LENSSEN et al., 1998]. Therefore common reed can easy sprout each growing season. A dry reed stems can stay for a long time (up to 2 years) and prevent germination of new shoots. Observations in Danube biosphere reserve [ZHMUD, 2006] proved that yield significantly decreases in old reed stands which have been neither harvested nor burned for many years.

There are convincing evidences that regular mowing at the end of growing season or every 2 years does not necessarily cause a subsequent decrease of reed mass; in some cases abundance and mass values even increased over 5-6 years [GÜSEWELL et al., 2000]. In contrast, additional harvesting in summer or autumn can rather induce biomass fall [WEISNER AND GRANÉLI, 1989; HELLINGS AND GALLAGHER, 1992], in particular, by 25-30 \% compared with a control since the third year of experiment [GÜSEWELL et al., 2000]. Livestock grazing can induce a significant fall of reed abundance just in 2-3 years [VAN DEURSEN AND DROST, 1990].

Considering the above historical and environmental facts we should obviously admit that harvesting some of reed in winter is a good practice to keep stability of wetlands with the minimum harm for environment and revival of traditional rural forms of land use in the newly established Park. We adopted a traditional technique of harvesting used in the practice of Danube biosphere reserve as recommendations for managing wetlands with reeds [VoloshKeVych et al., 2001; THE Procedure ReCOMMENDATIONS..., 2007]: winter harvesting cycle once per 2 years; mowing reed not continuously, plot-by-plot but in alternating lanes, by hands or machines when ground is frozen or ice cover emerges; retaining at least $25 \%$ of reeds; monitoring on $100 \mathrm{~m}^{2}$ control plots. Dense and moderate-dense reeds (150-200 or more stems per $1 \mathrm{~m}^{2}$ ) are of a little attractiveness for mammals and birds so that animals avoid over-grown sites. On the other hand, certain animals can maintain normal life 
activity if only having large areas of reeds, for instance, birds such as Botaurus stellaris L. and Circus aeruginosus L occasionally occurring in the Park need reeds of 25 ha or more square.

\section{Conclusions}

In the Park reed grows on large areas in eutrophic conditions. It is a highly competitive plant with stands mostly of low and moderate density. The most productive sites are under regular flooding; less productivity is observed on not regular, long-flooded sites; the expected yield is $13-17 \mathrm{t}^{*} \mathrm{ha}^{-1}$ and $2-7 \mathrm{t}^{*} \mathrm{ha}^{-1}$, appropriately. After a long period of undisturbance the first winter harvesting did not affect reed stands in the first year of observations. An intentional removal of some reed in winter can be accepted if minimum squares of reeds are at least 70 ha with proportions of harvesting 3:2 ( 3 parts of reed to be removed, 2 - to preserve); and at least 106 ha with harveting proportions 3:1. So there would be retained not harvested $26-27$ ha of reeds on each site in order to conserve animal species associated with reeds.

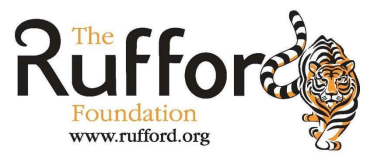

\section{Acknowledgements}

This research is conducted under support of the Rufford Foundation in the framework of the Rufford Small Grant project «Preservation Of Floodplain Landscapes Within The National Nature Park 'Pyriatynsky', Dnipro River Basin, Ukraine».

Authors express their gratitude to: $\mathrm{PhD}$. Oleksandr Golubtsov, a doctoral candidate of the Institute of Geography of National Academy of Sciences of Ukraine, for given classification of types of landscapes, identification of soil types and also for other research assistance; the administration of the national nature park "Pyriatynskyi" and staff of its Research Department and State Protection Service, for assistance in field examinations.

\section{References}

Bodensteiner L.R., GABRIEL A.O. (2003). Response of mid-water common reed stands to water level variations and winter conditions in Lake Poygan, Wisconsin, USA. / Aquatic Botany, 76: 49-64. doi:10.1016/S0304-3770(03)00013-5

Buttler A. (1992). Permanent plot research in wet meadows and cutting experiment. Vegetatio, 103: 113-124.

Dubyna D.V., Shelyag-Sosonko Yu.R. (1989). Wetlands of the Black Seaside region. Kyiv, Naukova dumka. (in Russian).

Dubyna D.V., Stupak A.P., Nebesnyi V.B. (1990). Distribution, ecological and phytosociological attributes and resource funds of common reed in the mouth area of the Dnieper river. Bull Of the Moscow Society of Naturalists Biol Sect., 95 (1): 77-87. (in Russian).

Granéli W. (1984). Reed Phragmites australis (Cav.) Trin ex Steudel as an energy source in Sweden. / Biomass. 4: 183-208. doi:10.1016/0144-4565(84)90056-8

GRANELI W. (1989). Influence of standing litter on shoot production in reed, Phragmites australis (Cav.) Trin. ex Steudel. Aquatic Botany, 35: 99-109.

GRANÉLI W. (1990). Standing crop and mineral content of reed in Sweden - management of reed stands to maximize harvestable biomass. / Folia Geobotanica et Phytotaxonomica, 25: 291-302.

GRYSEELS M. (1989). Nature management experiments in a derelict reedmarsh. I. Effects of winter cutting. Biological Conservation, 47 (3): 171-193. doi:10.1016/0006-3207(89)90063-3

Güsewell S., Le NÉDic C., ButTler A. (2000). Dynamics of common reed (Phragmites australis Trin.) in Swiss fens with different management. Wetlands Ecol. Manag., 8: 375-389. doi: 10.1023/A:1026553700571

Hanganu J., Mihail G., CoOps H. (1999). Responses of ecotypes of Phragmites australis to increased seawater influence: a field study in the Danube Delta, Romania. Aquatic Botany, 64: 351-358. doi: 10.1016/S0304-3770(99)00062-5

Hellings S.E., Gallagher J.L. (1992). The effects of salinity and flooding in Phragmites australis. J Appl Ecol., 29: 41-49. 
Komulainen M., PÄIVI S., Hagelberg E., IKONEN I., LYytinEN S. (2008). Reed energy - possibilities of using the common reed for energy generation in Southern Finland. - Turku, Turku University of Applied Sciences, 5-77.

Lenssen J.P.M., Ten Dolle G.E., Blom C.W.P.M. (1998). The effect of flooding on the recruitment of reed marsh and tall forb plant species. Plant Ecol., 139: 13-23. doi: 10.1023/A:1009754505028

Mynarchenko V.M., SeredA P.I. (2004). Resource science: medicine plants. Kyiv, Phytosociocentr,71 p. (in Ukrainian).

RolletscheK H., RolletscheK A., Kühl H., Kohl J.G. (1999). Clonespecific differences in a Phragmites australis stand II. Seasonal development of morphological and physiological characteristics at the natural site and after transplantation. Aquatic Botany, 64: 247-260. doi: doi:10.1016/j.aquabot.2006.11.005

Movchan Ya.I. (ed) (2007). The Procedure Recommendations on Environmentally Safe Harvesting (Through Cutting) of Common Reed. - Kyiv, NGO “Sribna Chaika”. (in Ukrainian). http://necu.org.ua/ocheret/

VAn der Sluis Th., Poppens R., Kraisvitnit P., RiI O., Lesschen J.P., Galytska M., Elbersen W. (2013). Reed harvesting from wetlands for bioenergy: Technical aspects, sustainability and economic viability of reed harvesting in Ukraine. - Wageningen, Alterra Wageningen UR. 87 pp.

Thevs N., Zerbe S., Gahlert F., Mijit M., Succow M. (2007). Productivity of reed (Phragmites australis Trin. ex Steud.) in continental-arid NW China in relation to soil, groundwater, and land-use. J of Appl Botany and Food Quality, 81: 62-68.

VAn der Putten W.H., Peters B.A.M., Van Den Berg M.S. (1997). Effects of litter on substrate conditions and growth of emergent macrophytes. New Phytologist, 135: 527-537. doi: 10.1046/j.1469-8137

VAN DER TOORN J., MOOK J.H. (1982). The influence of environmental factors and management on stands of Phragmites australis. I. Effects of burning, frost and insect damage on shoot density and shoot size. $J$ Appl Ecol., 19: 477-499.

Van Deursen E.J.M., Drost H.J. (1990). Defoliation and treading by cattle of reed Phragmites australis. J Appl Ecol., 27: 284-297.

VoloshkeVYCH A., ZHMUd Ye., ZHMUd M. (2001). Nature conservations aspects of the economical utilization of common reed in the Danube biosphere reserve. Sci. Notes of Volodymyr Gnatiuk State Pedagogical University of Ternopyl Biol Ser., 4: 206-207. (in Russian).

WEISNER S.E.B., GRANÉLI W. (1989). Influence of substrate conditions on the growth of Phragmites australis after a reduction in oxygen transport to below-ground parts. Aquatic Botany, 35: 71-80. doi:10.1016/0304-3770(89)90068-5

Wichtmann W, Joosten H. (2007). Paludiculture: peat formation and renewable resources from rewetted peatlands. International Mire Conservation Gr Newsletter. 3: 24-28.

Wichtmann W., TANNEBERGER F., BÄRISCH S. (2009). Feasibility of the use of biomass from re-wetted peatlands for climate and biodiversity protection in Belarus: http://www.succowstiftung.de/project_reports.html. Accessed December 2009.

Рекомендує до друку

Отримано 03.09.2014

Д.В. Дубина

Aдреса автора:

О.С. Абдулоєва

A.В. Подобайло

Київський національний університет

ім. Тараса Шевченка

вул. Володимирська, 60

Київ, 01601, Україна

e-mail:oksana_abduloieva@univ.kiev.ua,

oksasteppe@gmail.com

\author{
Authors' address: \\ Oksana S. Abduloieva \\ Anatoliy V. Podobaylo \\ Kyiv Taras Shevchenko National University, \\ 60, Volodymyrska str. \\ Kyiv, 01601, Ukraine \\ e-mail:oksana_abduloieva@univ.kiev.ua, \\ oksasteppe@gmail.com
}

